\title{
Circulating Stem Cell
}

National Cancer Institute

\section{Source}

National Cancer Institute. Circulating Stem Cell. NCI Thesaurus. Code C115116.

A primitive cell found in the peripheral blood that has the ability either to divide and renew the primitive cell pool or to differentiate into various specialized cell types. 